\title{
A new species of Heleomyza Fallén from Hokkaido, Japan (Diptera; Heleomyzidae)
}

\author{
Tsunemaru Oradome \\ Entomological Laboratory, Faculty of Agriculture, Meijo University, \\ Tenpaku-ku, Nagoya 468, Japan
}

(Received: September 17, 1993)

Key words: Heleomyzidae, Heleomyza, taxonomy, new species, Japan.

Recently, through the courtesy of Dr. M. Iwasa, I had an opportunity to examine 4 males and 4 females of Heleomyza species preserved in the Laboratory of Entomology, Obihiro University of Agriculture and Veterinary Medicine, Obihiro, Hokkaido.

The genus Heleomyza, belonging to the subfamily Heleomyzinae, includes 23 species of which 11 occur in the Palearctic region (Gorodkov, 1984), nine in the Nearctic region (Gill, 1965), and three in both Palearctic and Nearctic. In Japan, only one species of the genus has been recognized by Okadome (1965, 1971).

The result of my examination has revealed that they belong to a new species which is similar to $H$. bisetata (Garrett) from Nearctic region (Gill, 1962, 1965) to be described below.

\section{Key to the Japanese species of Heleomyza Fallén}

1. Mesopleuron bare except for short hairs near propleuron; hind basitarsus with a small and sharp ventral tooth at the distal end; hind basitarsus thickened and shorter

\footnotetext{
* 岡留恒丸：名城大学農学部 (厂4.68 名古屋市天白区 塩釜口 1-501)
}

than the following segment ......... ................. iwasai n. sp. Mesopleuron with 1 or 2 bristles restricted to middle of posterior margin other than about 10 hairs near propleuron; fore and hind basitarsi each with a small ventral tooth at the distal end; hind basitarsus thickened and equal in length to the following segment ................ ........... H. eoa (Gorodkov, 1962)

\section{Heleomyza iwasai n. sp.}

Male. Head quadrated in lateral view; frons yellow to yellowish brown becoming pale yellow anteriorly; upper half of front-orbital plates, vertex and upper back of head ash to ash brown; width at level of orbital bristles about 1.4 times at the length from anterior ocellus to frontal margin; sides virtually parallel and densely clothed with short setulae anteriorly; 1st and 2nd segments of antenna yellowish brown, 3rd segment becoming dark brown towards anterior margin, and arising from upper half of the middle of head; anterior front-orbital bristles equal in height to the posterior bristles; 2 very long vibrissae and irregularly placed 2 or 3 rows of buccal setae present; margin of orbital plates reddish 

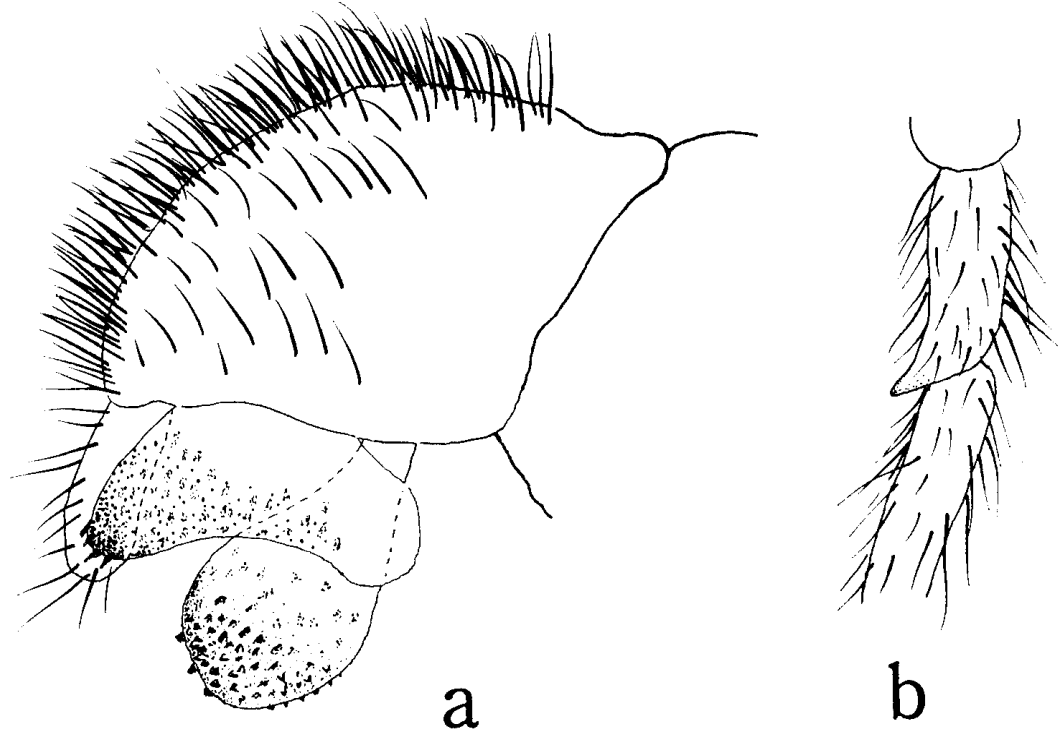

Fig. 1 Heleomyza iwasai n. sp. (male).

a: genitalia, lateral view. b: left hind basitarsus.

brown; palpi yellowish brown.

Thorax dark grey, covered with ash pollen; dorso-central bristles except for fine mesonotal setae on dorsum marked with brownish black spot at base; scutellum paler than mesonotum, rather rounded apically; 2 strong strenopleural bristles, with about 10 small hairs or setae.

Legs yellowish brown; tarsi distinctly darkened towards distal end; fore femur with a row of about 5 or 6 long bristles on dorsal, and sparsely with some bristles on posterolateral surfaces; all tibiae with a dorsal preapical bristle; middle tibia with 2 or 3 strong and some weaker bristles ventrally at the distal end; fore and mid basitarsi about twice as long as the following segment; hind basitarsus thickened and shorter than the following segment, and with a small and sharp ventral tooth at the distal end; costal spines about as long as anterior cross-vein.

Abdomen dark grey; epandrium small and yellowish brown; about 1.2 times longer than height, hairs on dorsum short and dense; surstylus somewhat spoon-shaped, inner surface apically with some short spine-like bristles, especially densely at outer margin; edita curved triangularly, inner surface of posteroventral corner with some spine-like bristles.

Length: body $4.5 \mathrm{~mm}$, wing $5.0-5.5 \mathrm{~mm}$.
Female. Similar to male, except for terminalia; hind basitarsus equal in length to the following segment and lacking a small ventral tooth at the distal end.

Length: body $5.0-5.5 \mathrm{~mm}$, wing $5.5-6.0$ $\mathrm{mm}$.

Holotype: Male, Ashoro, Hokkaido, 1 June 1989, M. Iwasa. Paratypes 3 male exs. and 4 female exs., same data and locality as for holotype.

Holotype and paratypes deposited in Entomological Laboratory, Faculty of Agriculture, Meijo University, Nagoya.

Distribution. Japan (Hokkaido) .

This species was bred by Dr. M. Iwasa from the nest of "Blackiston's Fish Fowl," Ketupa blakistoni (Striges) [Strigiformes: Strigidae].

The new species is named after Dr. Mitsuhiro Iwasa, who first discovered this species in Ashoro, Hokkaido.

Structurally this species is extremely similar to Nearctic H. bisetata (Garrett, 1922), but lacking a small ventral tooth at the distal end of fore basitarsus and dorso-central bristles arising from brownish black spots.

\section{ReFERENCES}

Garrett, C. B. D. (1922) : New species of Helomyzidae. Ins. Insc. Menstr., 10(10-12) : 175- 
177.

Gill, G. D. (1962): The Heleomyzid flies of America north of Mexico (Diptera: Heleomyzidae). Proc. U. S. Natl. Mus., 113: 495-603.

Gill, G. D. (1965): Family Heleomyzidae. In: $A$ Catalog of the Diptera of America North of Mexico, pp. 808-816, USDA, Washington, D.G.

Gorodkov, K. B. (1962): Revision of the Palearctic species of the genus Leria R.-D. (Diptera: Heleomyzidae). Entomol. Obozr., 41: 643-6471 (in Russian).

Gorodkov, K. B. (1984): Family Heleomyzidae. In: Catalogue of Palearctic Diptera (eds., Soós, A. and L. Papp), pp. 15-45, Akadémiai Kiadó, Budapest.

Okadome, T. (1965): Some records of the Japanese heleomyzid species. In: Abstract of the 25th Annual Meeting of Entomol. Soc. Jpn., p. 3 (in Japanese).

Okadome, T. (1971): On the scientific names

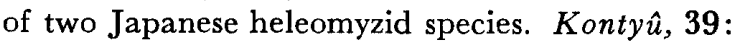
67-68 (in Japanese).

\section{摘 要}

北海道産 Heleomyza 属トゲハネバエ科の 1 新種 本属のトゲハネバエは，現在およそ23種が報告され ているが，日本からはこれまでわずかに 1 種が記録さ れているにすぎない. H. izeasai Okadome n. sp. フ クロウトゲハネバエ (新称) は, 帯広畜産大学の岩佐 光啓助教授によって, Ketupa blakistoni (Striges) シ マフクロウの巢から飼育されたもので, 後脚基跱節が 前・ 中脚のものに比較して太く，しかも第二跗節より も短く，また末端腹面に尖った小粎をもつことなどの 特徴により近似種と異なる。 